\title{
Determinants of Job Satisfaction and Employee Performance in Classified Hotels
}

\author{
R.A.D.D.N. Ranatunga \\ Department of Tourism \& Hospitality Management, Faculty of Management Studies, Rajarata University of Sri \\ Lanka, Mihintale \\ dinunawanji@gmail.com
}

\begin{abstract}
This study aims to identify the Relationship between Pay, Promotion, Supervision, Coworkers and Work itself of Job Satisfaction and Job Performance among Employees in Classified Hotels. Though the available literature does not provide sufficient empirical evidence to the respective study. Hence, the objective of this study was to find out Relationship between Pay, Promotion, Supervision, Co-workers and Work itself of Job Satisfaction and Job Performance among Employees in Classified Hotels. The study was chosen 150 non-executive employees as the sample and used the convenience sampling method. Moreover, the study used a structured questionnaire to collect the data. Internal consistencies of the questionnaire were measured using the reliability static Cronbach's alpha. Frequencies, univariate analysis, Pearson's correlation, T-test and multiple regression analysis as multivariate analysis were the analysis which used in the study. The results of the correlation coefficient were shown that pay, promotion, co-workers, supervision, work itself has a significant positive relationship with job performance and it emphasized that the factors pay and co-workers have a strong relationship with job performance. According to the multiple regression analysis, the model was strongly fitted to the data and $40.6 \%$ variance of job performance was explained by pay, promotion, coworkers, supervision and work itself of job satisfaction. Consequently, it can be recommended that future researchers should concern about the other factors which may also have a relationship with job performance. Lastly, it can be concluded that there is a significant positive relationship between selected factors of job satisfaction and job performance of employees in Classified Hotels. Based on the findings of the study, it is recommended for management to advance and sustain job satisfaction in the hotel industry to deepen the job performance of employees.
\end{abstract}

Keywords: Job satisfaction, Job performance, Pay, Promotion, Co-workers, Supervision, Work itself, Star Hotels 


\section{Introduction}

Today, the tourism sector acts an important role in the development of a country's economy. Countries across the globe compete for tourists. Tourism plays a crucial role in bringing foreign currency into the country, which in turn stimulates the economy. The hospitality industry is the primary source of support for tourists and visitors seeking accommodation during their visit. (Almutairi, Moradi, Idrus, Emami, \& Alanazi, 2013). As a service-based industry, the hospitality industry incorporates the biggest sector of the tourism industry and it can be recognized as the heart of the industry (Rogerson \& Kotze, 2011). Employees are the core ingredients of hospitality service as they are the ones who mainly provide the service. Since least time splits the production of the service from its delivery, the impression of providing workers with the flexibility, autonomy, and capability to encounter customer service demands as they arise is instinctively appealing (Hechanova, Alampay, \& Franco, 2006). Where employees are happy with their jobs, they tend to offer a high level of service to customers. Satisfied employees tend to be more productive, positive and creative than the ones who are not satisfied (Kong, Cheung, \& Zhang, 2010). Since human capital is the main challenge in-service process, most organizations strive to improve job performance amongst their employees for attaining high levels of productivity, efficiency and effectiveness (Cho, Woods, \& Erdem, 2006). In recent decades, job satisfaction has become a burning topic of research as it is positively linked to the job performance of the employees and organizational performance (Gu \& Siu, 2009). This is why considerable attention has been given by researchers in this hospitality industry (Edwin \& Sheryl, 2013). The hotel sector faces enormous competition and a vibrant environment (Murasiranwa, Nield, \& Ball, 2010). When insisting on the unceasing deliberations on the challenges faced by the hotel industry in Sri Lanka, human involvement has played a significant organizational role (Weerakkody \& Perera, 2016). Relocating abroad for high wages, lack of competent employees, etc., are a few human resource issues in the industry, which makes a massive obstacle to lessen the effort to reach organizational objectives. Consequently, employees play the most crucial role in fostering competitive advantage that influences organizational 
performance (Lankeshwara, 2016). Because they can be the same for different organizations, but the individuals representing two organizations are not the same, and it is reasoned to act in order to gain a competitive advantage (Jayarathna, 2014).

With productivity, becoming a dominant issue in today's hospitality industry, all positions in the employee category have a vital role to play in maintaining the highest labour productivity in this sector (Weerakkody \& Perera, 2016). Gaining productivity through job performance positions have done extensive research into the literature on organizational behaviour and human resource development (Bommer, et al., 1995). Based on the quantity and quality intended for each employee, job performance may be identified. Most organizations operate well with the support of effective employees (Khan, Khan, \& Khan, 2011). Most organizations perform well with the assistance of efficient employees.

Of these, job satisfaction is an important pathway to decide how hard employees work in an organization. (Locke, 1976). For instance, a happy employee outperforms an unsatisfied employee. Once an employee succeeds, it is a competitive advantage for an organization and there is justification for surviving in the competitive marketplace (Munisamy, 2013). In general, an increasing relationship can be observed between employee satisfaction and customer satisfaction and ultimately with organizational performance, in service organizations (Hallowell, Schlesinger, \& Zornitsky, 1996).

Like all organizations, Hotels also operate for a purpose. They should costeffectively use their scarce resources to reach their goals and objectives. To obtain a competitive advantage, hotels need human resources with well job performance because it is a unique resource special feature. When considering the challenges faced by Hotels in the Sri Lankan scenario, human resource issues become a major issue. In today's fast-paced and turbulent market environment, it is vitally important to obtain and maintain a pool of employees who possess the personal qualities necessary for the effective performance of work in the workplace. (Karatepe, Keshavarz, \& Nejati, 2010). Considering their satisfaction can be considered as important as it impacts the performance of employees. 
Furthermore, the available literature does not provide sufficient evidence on the impact of employee job satisfaction in hotels classified in the Sri Lankan context. Precisely, this study has 06 objectives.

I. To find out the relationship between Pay and Job Performance among Employees in Classified Hotels

II. To find out the relationship between Co-workers and Job Performance among Employees in Classified Hotels?

III. To find out the relationship between Supervision and Job Performance among Employees in Classified Hotels

IV. To find out the relationship between Supervision and Job Performance among Employees in Classified Hotels

V. To find out the relationship between Work itself? and Job Performance among Employees in Classified Hotels

VI. To find out the difference between Gender and Job Performance of Employees in Classified Hotels

\section{Significance of the Study}

The findings of the study offer the empirical data for literature review. Moreover, this study is important to the existing theories which support clarifying and boost the significance of job satisfaction to the employees from this study. Accordingly, it supports making the job satisfaction theory more complete in terms of the relationship among the two variables, that is the independent and dependent variables.

This study is important to assist data and facts which had been done by previous searchers. The study used a survey questionnaire and a pilot test to collect data from respondents to make certain the questions accomplish the minimum standard of validity and reliability analysis that can assist more accurate findings and outcomes. The validity and reliability test were conducted to test all the instruments which were used in the study as the study can maximize the level of validity and reliability set and produce a more appropriate and precise study. Moreover, the study is also capable 
of further clarifying any ambiguous matters linked to the field of this study that was done by previous researchers.

\section{Pay}

The employees pay is a significant aspect that assures the willingness to do the job well to increase job performance. Therefore, organizations need to develop a good compensation system that is able to satisfy their employees in order to increase their job performance in the organization. The total of financial payment which is received and the extent to which this is noticed as equitable compared to others in the organization. Wages and salaries are important but at the same time, they can be identified as a cognitively multifaceted and multidimensional feature in job satisfaction. Employees need money for the fulfilment of their basic needs as same as their higher-order level needs. They are usually viewed as pay by means of a reflection of how management observe their contribution to the organization. Fringe benefits are also vital, however, they are not influential because most employees do not even recognize how much they are getting in benefits. Furthermore, misunderstanding of their important monetary value tends to undervalue these benefits (Luthans, 2011).

\section{Promotion}

The opportunities for advancement in the organization can be defined as a promotion. Promotions affect job satisfaction in various ways because they can be identified in several forms. For example, the employees who get promotions depend on their seniority less satisfied than the employees who get their promotions on their performance (Luthans, 2011).

\section{Co-workers}

The extent to which parallel employees are technically proficient and socially helpful can be defined as co-workers. The nature of the work group or team will affect job satisfaction. Friendly, supportive co-workers are a modest cause of job satisfaction of employees, and tight workgroups function as a source of assistance, well-being, and 
guidance to the individual employees, likewise the environment of workgroup affects job satisfaction (Luthans, 2011).

\section{Supervision}

The capabilities of the supervisor to deliver technical support and behavioural support can be defined as supervision. There are two aspects of supervisory styles which affects job satisfaction. They are employee-centeredness, and participation/influence as illustrated by managers. Employee-centeredness is measured by the extent to which a supervisor takes individual attention and cares about the employee. As examples; examine to see exactly how well the employee is working, offering advice and support to the employee, and interactive with the subordinate on a personal as well as an official level. Participation or influence, as demonstrated by managers who let their individuals take part in decisions that influence their jobs is the other aspect of supervisory style. This style impacts greater job satisfaction than the other. If the supervisor creates a participative environment it will have a more considerable consequence on employees' satisfaction than participation in a specific decision (Luthans, 2011).

\section{Work itself}

The degree to which the job offers the individual stimulating tasks, chances for learning, and the opportunity to receive responsibility. The content of the work itself is a key source of satisfaction (Luthans, 2011).

\section{Job Satisfaction}

Job satisfaction is a sentimental or emotional response towards different features of an employee's work. Probable causes of job satisfaction include supervision, coworker relationships, remuneration and extrinsic rewards, promotion and work itself (Schermerhorn, 1993). Job satisfaction occurs when a job meets the expectations, values and standards of an individual and will influence their commitment and performance (Gordon, 1999). Job satisfaction is an approach, researchers should be cautioned to recognize the goals of cognitive evaluation, which are affected by 
feelings, convictions and practices (Weiss, 2002). Shaikh, Bhutto, and Maitlo (2012) conducted a study among bank employees in Pakistan and they have emphasized that work, co-workers, supervision, pay and promotion as measures of job satisfaction and they have a substantial and solid impact on overall job satisfaction level. Five job measurements have been accepted in later years to designate the most significant characteristics of a job about which employees have satisfaction responses and it is generally used to measure job satisfaction over the years. Additionally, a metaanalysis has confirmed their construct validity (Luthans, 2011).

\section{Job Performance}

Job Performance is the execution of an individual's work when spread over required strength on the work which is involved outline, grew over fulfilment of expressive work, and empathetic co-workers/employers all over the place (Karakas, 2010). Job performance consists of quality and quantity of values motivated from a person or group struggle success (Shockley-Zalabak, Ellis, \& Winogard, 2000). It can be defined as behaviours which related to organizational goals and under the resistance of individual workers (Sony \& Mekoth, 2016). Motowidlo and Van Scotter (1994) specified that performance is shaped by behaviours or actions which allied with the goals of an organization. Moreover, job performance is the action or behaviour itself and not the consequence of activities or a result. Each employee employed within an organization is projected to execute his/her tasks and duties effectively in an accountable method in accordance with the employment contract. Eventually, the employees do their job reliably and experience a feeling of responsibility for performing well (Opatha, 2012). Through the predisposition and truthfulness employees can enhance their productivity that eventually leads to the performance of the employees (Sinha, 2001). Pearce (1992) explained that job performance is one of the important symbols in measuring organizational performance. Job performance can be measured by using two measurements as task performance and contextual performance. Job performance is derived as outcomes of two aspects (Salanova \& Kirmanen, 2008; Sarmiento \& Beale, 2007; Wall et al., 2004). It encompasses the natural or attained abilities and skills that can be used to carry out a better job. Ideally 
grouped into two distinct levels as task performance and contextual performance. For instance, task performance is ingestion of a continuous great standard of work, and contextual performance means pointing new associates further than job purview (Pradhan \& Jena, 2016).

The following hypotheses could be drawn by the literature:

$\mathrm{H} 1$ : There is a significant relationship between pay and job performance of employees in Classified Hotels

$\mathrm{H} 2$ : There is a significant relationship between promotion and job performance of employees in Classified Hotels

H3: There is a significant relationship between co-workers and job performance of employees in Classified Hotels

H4: There is a significant relationship between supervision and job performance of employees in Classified Hotels

H5: There is a significant relationship between work itself and job performance of employees in Classified Hotels

H6: There is a significant difference between Gender and Job Performance of Employees in Classified Hotels

\section{Materials and Methodology}

This study intends to find the relationship between pay, promotion, co-workers, supervision, and work itself of job satisfaction and job performance of the employees in classified hotels. Accordingly, this explanatory research used the quantitative research approach to detect the stated relationship between independent and dependent variables. There are five independent variables used to determine the dependent variable. They are Pay, Promotion, Co-workers, Supervision and Work itself. The dependent variable is Job Performance. 


\section{Conceptual Framework}

Based on the hypothesis employees job performance depends on five factors of job satisfaction as pay, promotion, co-workers, supervision and work itself. Job performance of employees' is considered as the dependent variable. Consequently, pay, promotion, co-workers, supervision and work itself are labelled as independent variables.

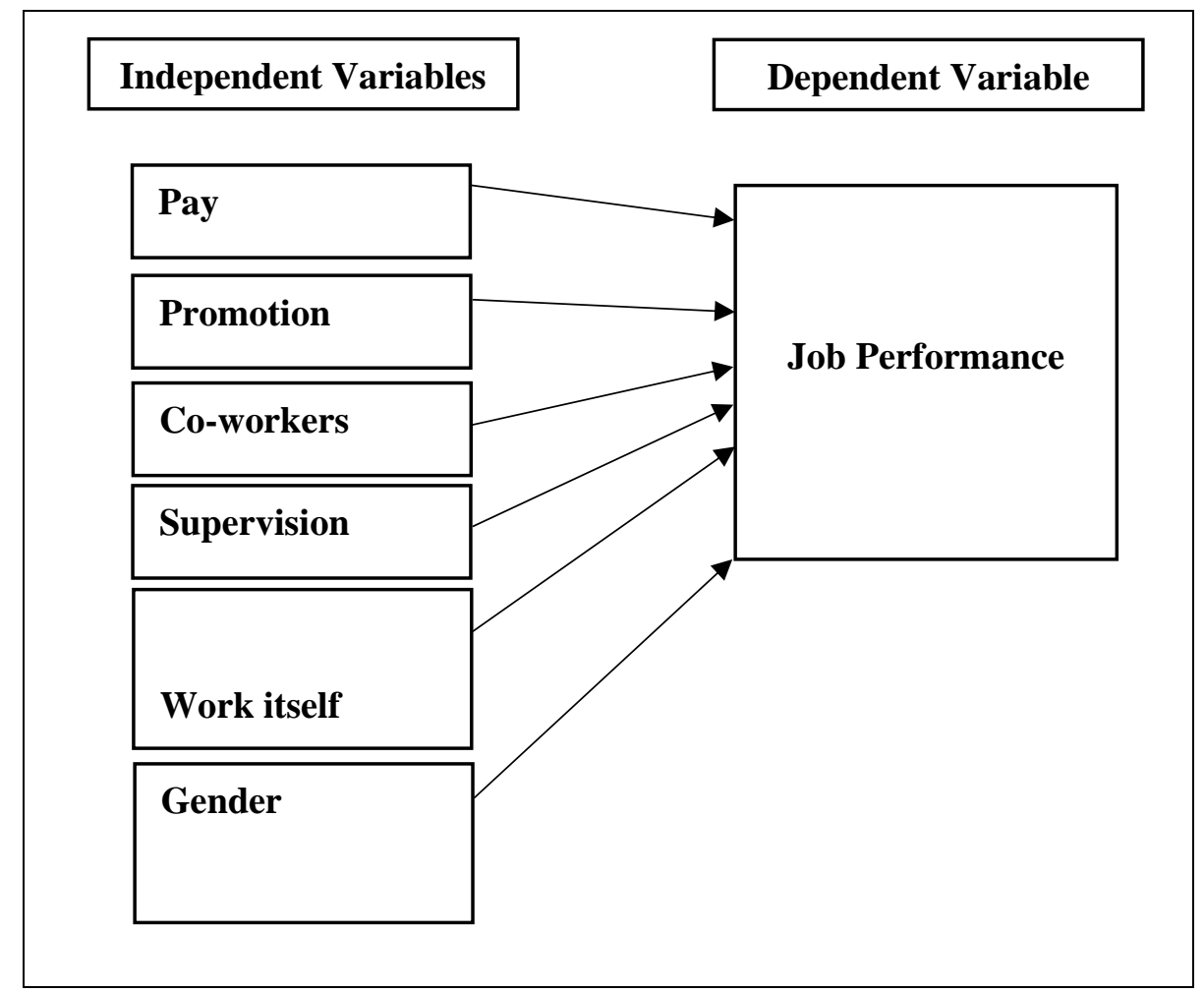

Figure 1. Conceptual Framework Source: Developed by the author, 2019

\section{Population and Sampling Technique}

The study was used non- executive employees of classified hotels in the Kandy district as the target population. Classified Hotels were selected by referring to the accommodation guide issued by Sri Lanka Tourism Development Authority. Since there weren't any sources to recognize the exact amount of population it was 
recognized as an undefined population. The study was used the convenience sampling technique to choose the sample from the population since it was not probable to reach all the non-executive employees of star class hotels to be contributed to the study because the study was conducted during the peak season in the tourism industry and the hectic work atmosphere of hotels. 200 questionnaires were distributed among employees and the study was used 150 as the sample since there were incomplete and inaccurately filled questionnaires. Non-executive employees who work in the main 04 departments (Front Office, Food and Beverage, Kitchen and Housekeeping) consists in the study.

\section{Research Instruments}

Fundamentally, the study was used a quantitative research method to collect information. A questionnaire that contained three main sections was used as a research instrument. The first section contained demographic factors, the second section comprised of questions related to job satisfaction and the third section contained questions associated with the job performance questions.

In this study, two measures were chosen from established sources. Weiss, Dawis, England, \& Lofquist (1967) measure for job satisfaction and Befort \& Hattrup (2003) measure for task performance and contextual performance. A 5-point Likert scale was used to measure the dependent and independent variables.

\section{Results and Interpretations}

Reliability analyzes, descriptive analysis, correlation analyzes of the dependent and independent variables, T-Test was done to realize the set objectives and to assess hypotheses of the study.

\section{Demographic Profile of the Respondents}

Below TABLE 1 shows that the largest proportion under the gender category represent the male respondents $(62 \%)$ and in the age category majority of the respondents comes under the 25-34 age category. $32.7 \%$ of respondents passed 
Ordinary Level and $36 \%$ of the respondents out of all respondents have married. Furthermore, $49.3 \%$ of respondents have less than 2 years of service.

\begin{tabular}{|c|c|c|c|}
\hline Demographic factor & Category & Frequency & Percentage \\
\hline \multirow[t]{2}{*}{ Gender } & Male & 93 & $62 \%$ \\
\hline & Female & 57 & $38 \%$ \\
\hline \multirow[t]{4}{*}{ Age } & Less than 25 & 36 & $24 \%$ \\
\hline & $25-34$ years & 58 & $38.6 \%$ \\
\hline & $35-44$ years & 28 & $18.7 \%$ \\
\hline & 45 and above & 28 & $18.7 \%$ \\
\hline \multirow{5}{*}{$\begin{array}{l}\text { Education } \\
\text { qualification }\end{array}$} & $\mathrm{O} / \mathrm{L}$ & 49 & $32.7 \%$ \\
\hline & $\mathrm{A} / \mathrm{L}$ & 37 & $24.7 \%$ \\
\hline & Diploma & 28 & $18.6 \%$ \\
\hline & Graduate & 18 & $12 \%$ \\
\hline & Other & 18 & $12 \%$ \\
\hline \multirow[t]{5}{*}{ Marital status } & Married & 54 & $36 \%$ \\
\hline & In a relationship & 40 & $26.7 \%$ \\
\hline & $\begin{array}{l}\text { Single, never } \\
\text { married }\end{array}$ & 42 & $28 \%$ \\
\hline & Single, divorced & 09 & $6 \%$ \\
\hline & Single, widowed & 05 & $3.3 \%$ \\
\hline \multirow[t]{3}{*}{ Length of service } & Less than 2 years & 74 & $49.3 \%$ \\
\hline & $3-5$ years & 40 & $26.7 \%$ \\
\hline & 6 and above & 36 & $24 \%$ \\
\hline
\end{tabular}

Table 1: Demographic Profile of the Respondents Source: SPSS Software

\section{Reliability}

The internal consistency of the constructs which were used to measure the key variables of the study is reviewed by reliability. In accordance with that intention, 
Cronbach's Alpha test was performed by the researcher. The results are shown in TABLE 2.

\begin{tabular}{|l|l|l|}
\hline Variables & No. of items & $\begin{array}{l}\text { Cronbach's Alpha } \\
\text { value }\end{array}$ \\
\hline Pay & 05 & 0.889 \\
\hline Promotion & 05 & 0.714 \\
\hline Co-workers & 04 & 0.827 \\
\hline Supervision & 05 & 0.858 \\
\hline Work itself & 09 & 0.686 \\
\hline Job Performance & 12 & 0.943 \\
\hline
\end{tabular}

Table 2: Cronbach's Alpha Coefficient Value Source: SPSS Software

TABLE 2 emphasizes that 'Job Performance' denotes the highest Cronbach's alpha value (0.943) which is the dependent variable of the study. According to the rules of thumb of the reliability test, the value of the job performance ranges from 0.80-0.95 and designates very good reliability. Then 'Pay (0.889)', 'Supervision (0.858)' and 'Co-workers (0.827)' record the highest alpha values which fall into the category of 'very good reliability $(0.80-0.95)$ '. Then the dependent variable 'Promotion' has a 0.714 alpha value which can be identified as a 'good reliability' value (0.70-0.80). The 'Work itself' variable records an alpha value which is 0.686 and it ranges between $0.60-0.70$. Consequently, it can be identified as fair reliability by the rules of thumb of reliability and at the same time it is almost near to the range of 'good reliability'.

\section{Correlation Analysis}

The relationship between independent variables and dependent variable reviews under the correlation analysis and can be either positive or negative. The Pearson correlation analysis was used to measure the relationship between two variables and its value ranges from -1 to +1 . When the Pearson Correlation Coefficient value 
demonstrate +1 , there is a perfect positive correlation and on the other hand, if the value shows -1 , there is a perfect negative correlation. Other than that, when the Pearson Correlation Coefficient value shows 0 , it denotes that there is no correlation between a dependent variable and independent variables. The results are represented in table 3 given below.

\begin{tabular}{|c|c|c|}
\hline \multirow[b]{2}{*}{ Variable } & \multicolumn{2}{|c|}{ Job Performance } \\
\hline & $\begin{array}{ll}\text { Pearson } & \text { Correlation } \\
\text { Coefficient } & \end{array}$ & Sig. (2-tailed) \\
\hline Pay & 0.524 & 0.000 \\
\hline Promotion & 0.199 & 0.050 \\
\hline Co-workers & 0.674 & 0.000 \\
\hline Supervision & 0.275 & 0.030 \\
\hline Work itself & 0.460 & 0.000 \\
\hline
\end{tabular}

Table 3: Results of Correlations Analysis Source: SPSS Software

\section{Multiple Regression Analysis}

The technique that used to observe the variance in a single or more than one independent variable in a dependent variable.

\begin{tabular}{|l|c|c|c|c|c|}
\hline \multicolumn{5}{|c|}{ ANOVA } \\
\hline \multicolumn{1}{|c|}{ Model } & $\begin{array}{l}\text { Sum of } \\
\text { squares }\end{array}$ & Df & $\begin{array}{c}\text { Mean } \\
\text { square }\end{array}$ & F & Sig. \\
\hline Regression & 21.869 & 5 & 4.374 & 19.658 & $.000^{\text {b }}$ \\
\hline Residual & 32.039 & 144 & 0.222 & & \\
\hline Total & 53.908 & 149 & & & \\
\hline
\end{tabular}

Table 4: Results of ANOVA Test Source: SPSS Software

Above TABLE 4 shows that the Regression ANOVA probability of $\mathrm{F}$ test statistics is 0.000 which is less than 0.05 . Consequently, the overall model of the study is 
significant. Furthermore, all the independent variables impact job performance together.

\begin{tabular}{|l|l|l|l|}
\hline R & R Square & Adjusted R Square & Sig. F Change \\
\hline 0.637 & 0.406 & 0.385 & 0.000 \\
\hline
\end{tabular}

Table 5: Modal Summary Source: SPSS Software

Coefficient of determination ( $\mathrm{R}$ square value) and adjusted $\mathrm{R}$ square value are emphasized by the Regression modal. TABLE 5 shows that the $\mathrm{R}$ Square value is 0.406 and it describes the contribution made by the independent variables to the variation of the dependent variable. Accordingly, $40.6 \%$ variation in the dependent variable is showed by the selected independent variables. Moreover, the adjusted $\mathrm{R}$ square is $0.385(38.5 \%)$ which explains that the model is fitted to the data reasonably. In addition to that, the model's significant value is less than 0.05 . Thus, it can be concluded that the model is strong adequate to forecast future changes.

\section{Hypothesis Testing}

H1: There is a significant relationship between pay and job performance of employees in Classified Hotels

Correlation analysis was used to test the hypothesis and the correlation coefficient of pay is 0.524 (greater than 0.5 - strong relationship) and respective Sig. value is less than 0.05 ( $\mathrm{p}<0.05)$. Accordingly, "H1 is highly accepted" and it can be concluded that there is a statistically positive strong significant correlation between pay and job performance of employees of classified hotels. Most of the previous studies done by researchers revealed that there is a significant relationship between pay and job performance. Shaikh et al. (2012) conducted a study among bank employees in Pakistan and they have pointed out that pay is a measure of job satisfaction and it has a significant strong relationship with job performance. Du and Zhao (2010), these studies conclude that the pay was weak significant to the job performance. Pay is a significant element that motivates the employee's job performance and it has a significant relationship with job performance. 
H2: There is a significant relationship between promotion and job performance of employees in Classified Hotels

A correlation coefficient of promotion is 0.199 (0.0-0.3 weak relationship) and respective Sig. value is less than 0.05 . Accordingly, "H2 is highly accepted" and it can be concluded that there is a statistically positive weak significant correlation between promotion and job performance of employees of classified hotels.

A comparative study which was carried out by Mahmood and Baloch (2011) of the job satisfaction and job performance between private and public sector hospitals of Peshawar, revealed that there was a positive significant relationship between promotion and job performance. Furthermore, when the opportunities for advancement and growth in a considerable level, it leads to increased performance and a high productivity level. Finally, it was found that there is a significant positive relationship between promotion and job performance (Nimalathasan \& Brabete, 2016).

H3: There is a significant relationship between co-workers and job performance of employees in Classified Hotels

The correlation coefficient of promotion is 0.674 (greater than 0.5 - strong relationship) and respective Sig. value is less than $0.05(\mathrm{p}<0.05)$. Consequently, "H3 is highly accepted" and it can be concluded that there is a statistically positive strong significant correlation between co-workers and job performance employees of classified hotels. Some of the studies which have done by previous researchers revealed this relationship. A study that has observed the factors that affect job satisfaction in different private universities in Malaysia, has found that co-workers have a significant positive relationship with job performance (Bujang, 2011). The study which was carried out by Ahmadi (2009), used 923 nurses as the sample in Saudi Arabia in 15 randomly selected Ministry of Health Hospitals. In this job satisfaction-job performance study, it was found that there is a significant relationship between co-workers and job performance. 
H4: There is a significant relationship between supervision and job performance of employees in Classified Hotels

The correlation coefficient of promotion is 0.275 (less than 0.3 -weak relationship) and respective Sig. value is less than $0.05(\mathrm{p}<0.05)$. Accordingly, "H4 is highly accepted" and it can be concluded that there is a statistically positive weak significant correlation between supervision and job performance of employees of classified hotels.

A study that has been done on the relationship between job satisfaction and job performance of factory workers in Ahvaz observed that there is a significant positive relationship between supervision and job performance (Shokrkon \& Naami, 2009).

H5: There is a significant relationship between work itself and job performance of employees in Classified Hotels

The correlation coefficient of promotion is 0.460 (between 0.3-0.5 - moderate relationship) and respective Sig. value is less than $0.05(\mathrm{p}<0.05)$. Thus, "H5 is highly accepted" and it can be concluded that there is a statistically positive moderate significant correlation between work itself and job performance employees of classified hotels.

A study that was carried out on the relationship between facets of job satisfaction and task and contextual performance used a sample of 444 respondents in different tasks in a large manufacturing plant in Texas in the United States. The study revealed that there is a positive relationship between work itself and job performance and it is significantly related to employee performance.

H6: There is a difference between Gender and Job Performance of Employees in Classified Hotels

The t-test is used to test the hypothesis and it measures whether the means of two groups statistically vary from each other. This analysis is applicable to compare the means of the two groups. The researcher has used a T-test to analyse gender differences and job performance. 
An Independent sample t-test was performed to understand how the job performance of the employees defines the gender as follows.

\begin{tabular}{|l|l|l|l|l|l|}
\hline & Gender & N & Mean & $\begin{array}{l}\text { Standard } \\
\text { deviation }\end{array}$ & $\begin{array}{l}\text { Standard } \\
\text { error mean }\end{array}$ \\
\hline \multirow{2}{*}{$\begin{array}{l}\text { Job } \\
\text { performance }\end{array}$} & Male & 93 & 3.4194 & 0.60670 & 0.06291 \\
\cline { 2 - 6 } & Female & 57 & 3.5058 & 0.59431 & 0.07872 \\
\hline
\end{tabular}

\begin{tabular}{|c|c|c|c|c|c|c|c|c|}
\hline \multicolumn{7}{|c|}{ Independent Sample Test } & \multicolumn{2}{|c|}{$\begin{array}{l}95 \% \text { Confidence } \\
\text { interval of the } \\
\text { Difference }\end{array}$} \\
\hline & $\mathrm{F}$ & Sig. & $\mathrm{T}$ & Df & $\begin{array}{l}\operatorname{Sig}(2 \\
- \\
\text { tailed } \\
\text { ) }\end{array}$ & $\begin{array}{l}\text { Mean } \\
\text { differenc } \\
\text { e }\end{array}$ & Lower & Upper \\
\hline $\begin{array}{l}\text { Equal } \\
\text { variance } \\
\text { s } \\
\text { assumed }\end{array}$ & $\begin{array}{l}0.00 \\
9\end{array}$ & $\begin{array}{l}0.92 \\
3\end{array}$ & $\begin{array}{l}- \\
0.85 \\
4\end{array}$ & 148 & 0.394 & -0.8649 & $\begin{array}{l}- \\
0.2866 \\
2\end{array}$ & $\begin{array}{l}0.1136 \\
3\end{array}$ \\
\hline $\begin{array}{l}\text { Equal } \\
\text { variance } \\
\text { s not } \\
\text { assumed }\end{array}$ & & & $\begin{array}{l}- \\
0.85 \\
8\end{array}$ & $\begin{array}{l}120.46 \\
8\end{array}$ & 0.392 & -0.8649 & $\begin{array}{l}- \\
0.2860 \\
0\end{array}$ & $\begin{array}{l}0.1130 \\
2\end{array}$ \\
\hline
\end{tabular}

Table 8: Results of the Independent Sample T-test for Gender and Employee Performance Source: SPSS Software

According to Levene's test result, the variance means of the male and female was equal. Therefore, the result in the study used an equal variance assumed column to interpret the test. According to the independent test result, respective Sig. value is 
0.394. So it is greater than 0.05 . Therefore, "H6 is rejected" and this study concluded that there is no statistically significant difference between gender and job performance of employees in classified hotels.

\section{Conclusion}

Fundamentally, the study has gone through an introduction and revealed the research questions. By using those research questions researcher had developed below six objectives. (I) To find out the relationship between Pay and Job Performance among Employees in Classified Hotels (II)To find out the relationship between Promotion and Job Performance among Employees in Classified Hotels (III)To find out the relationship between Co-workers and Job Performance among Employees in Classified Hotels (IV)To find out the relationship between Supervision and Job Performance among Employees in Classified Hotels (V)To find out the relationship between Work itself and Job Performance among Employees in Classified Hotels (VI)To find out the difference between Gender and Job Performance of Employees in Classified Hotels.

Statistical Package for Social Sciences (SPSS) version 21.0 was the analytical tool used to analyze the result of the study. It was unable to reach all the employees of classified hotels to be participated in the study since the study was carried out in the peak season in the tourism industry and under the hectic work environment of hotels. The population of the study is undefined. So, there was no source to find out the exact population since the details were confidential. Therefore, the study was used a convenience sampling technique to select a sample from the population. Correlation analysis and T-Test was used to test the hypothesis of the study. According to that, H1, H2, H3, H4, H5 were accepted and H6 was rejected.

There were some limitations to the study. The main limitation of the study is, it is limited to a group of employees in the Kandy area. Thus it cannot be generalized to overall employees who are working at hotels in Sri Lanka as the study is limited to the Kandy area. Moreover, it was a bit hard to get true responses, which were related or most accurate to the character or attitude of a respondent. Particular rules and 
regulations inside the organization and their individual beliefs can be strongly affected to their answers. The findings in this study depend on the honesty of the respondents in responding to the questionnaire accurately.

This study will be advantageous for the human resource practitioners in the hotel industry since the findings can be used as guidelines to enhance the employee job performance and redesign the job which can lead to the employee's job satisfaction. Ultimately the practitioners can manage effective human resources. Moreover, the study has found out that the selected five factors (Pay, Promotion, Co-workers, Supervision, work itself) have a significant relationship with job performance. Out of the five factors pay and co-workers have a strong relationship with the job performance and work itself has a moderate relationship. Therefore, the study can be used by the managers to understand the significance of these job satisfaction factors in the organization. On the other hand, academically this study would fill the gap in the literature as it is done about the relationship between job satisfaction factors and job performance and it involves the element of specificity as it is conducted predominantly for the hotel industry. Plus, according to the empirical evidence, there were some researches on job satisfaction. But in the Sri Lankan context, few researches have been reported and it can be addressed the gaps which are currently existing in the literature especially in Sri Lanka and provide a more detailed link between theory and practice. Further, this study provides a better direction for future researchers who are interested in similar topics.

\section{Recommendations}

Job satisfaction and should be enhanced and maintain at a moderate level to increase the job performance of employees as results of the study show a positive significant relationship of job satisfaction factors between the job performance. Management of classified hotels can attempt to accentuate the fair and friendly management practices towards employees without ongoing with present practices. 
According to the study, human resource practitioners in the hotel industry can understand that especially pay, co-workers, work itself factors of job satisfaction can motivate the employees to improve their job performance. So, they can explore and use some organizational practices to enhance the satisfaction of the needs of the employees to retain them for a long period as the hotel industry is based on serviceoriented.

\section{References}

Almutairi, D., Moradi, E., Idrus, D., Emami, R., \& Alanazi, T. (2013). Job Satisfaction and Job Performance: A Case Study of Five-Star Hotels in Riyadh, Saudi Arabia. World Journal of Social Sciences, 3(1), 27-37.

Annual Statistical Report. (2019). Sri Lanka Tourism Development Authority.

Balzer, W., Kihm, J., Smith, P., Irwin, J., Bachiochi, P., Chet, R., . . Parra, L. (1997). Users

+ Manual for the Job Descriptive Index and the Job in General Scales. Bowling Green State University.

Beehr, T., \& Newman, J. (1978). Job stress, employee health, and organizational effectiveness: A facet analysis. Personnel Psychology, 31, 665-700.

Bommer, William, Johnson, Jonathon, Gregory, \& Podsakoff, M. (1995). On the Interchangeability of Objective and Subjective Measures of Employee Performance: A MetaAnalysis. 48.

Cho, S., Woods, R. J., \& Erdem, M. (2006). Measuring the Impact of Human Resource Management Practices on Hospitality Firms' Performances. International Journal of Hospitality Management, 25(2), 262-277.

Edwin, N., \& Sheryl, K. (2013). From Customer Satisfaction to Customer Delight: Creating a New Standard of Service for the Hotel. International Journal of Contemporary Hospitality Management, 25(5), 642-659.

Gharib, M., Jamil, S., Ahamed, M., \& Ghouse, S. (2016). The Impact Of Job Stress On Job Performance: A Case Study On Academic Staff At Dhofar University. International Journal of Economic Research, 13(1), 21-33. 
Gordon, J. (1999). Organsiational Behaviour: A Diagnostic Approach. New Jersey: Prentice Hall.

Griffin, R., \& Moorhead, G. (2010). Organizational Behaviour - Managing People and Organisations.

Gu, Z., \& Siu, C. (2009). Drivers of Job Satisfaction as Related to Work Performance in Macao Casino Hotels: An Investigation Based on Employee Survey. International Journal of Contemporary Hospitality Management, 21(5), 561-578.

Hallowell, R., Schlesinger, L., \& Zornitsky, J. (1996). Internal service quality, customer and job satisfaction: linkages and implications for management. Human Resource Planning, 19(2), 20-31.

Hechanova, M., Alampay, R., \& Franco, E. (2006). Psychological Empowerment, Job Satisfaction and Performance among Filipino Service Workers. Asian Journal of Social Psychology, 9, 72-78.

Jayarathna, S. (2014). An Empirical Investigation of the Impact of Employee Motivation and Productivity of Executive Employees with Special Reference to the Apparel Industry in Sri Lanka. International Journal of Science and Research, 3(3), 749-754.

Karakas, F. (2010). Spirituality and performance in organizations: A literature review. Journal of Business Ethics, 94(1), 89-106.

Karatepe, O., Keshavarz, S., \& Nejati, S. (2010). Do Core Self-Evaluations Mediate the Effect of Coworker Support on Work Engagement? A Study of Hotel Employees in Iran. Journal of Hospitality and Tourism Management, 17, 62-71.

Khan, R., Khan, F., \& Khan, M. (2011). Impact of Training and Development on Organizational Performance. Global Journal of Management and Business Research, 11.

Kim, G., Ro, H., Hutchinson, J., \& Kwun, D. (2014 ). The Effect of Jay-Customer Behaviors on Employee Job tress and Job Satisfaction. International Journal of Hospitality \& Tourism Administration, 15(4), 394-416. 
Kong, H., Cheung, C., \& Zhang, H. (2010). Career Management Systems: What are China's State-Owned Hotels Practising? International Journal of Contemporary Hospitality Management, 22(4), 467-482.

Lankeshwara, P. (2016). A study on the impact of workplace environment on employee's performance: with reference to the Brandix Intimate Apparel - Awissawella. International Journal of Multidisciplinary Studies, 3(1), 47-57.

Locke, E. (1976). The nature and consequences of job satisfaction.

Luthans, F. (2011). Organizational Behavior: An Evidence Based Approach.

Munisamy, S. (2013). Identifying factors that influences job performance amongst employees in oil palm plantation Faculty of Applied Social Sciences Open University Malaysia.

Opatha, H. (2012). Human Resource Management.

Pearce, D. (1992). Macmillan Dictionary of Modern Economics.

Pradhan, R., \& Jena, L. (2016). Workplace spirituality and organisational commitment: role of emotional intelligence among Indian banking professional. Journal of Human Resource Management, 19(1), 13-23.

R, A., Ing, H., \& Bujang, S. (2014, September). Relationship Between Selected Factors of Job Satisfaction and Job Performance among Workers at Oil Palm Industries. International Review of Management and Business Research, 3(3), 1751-1766.

Robbins, S., \& Judge, T. (2013). Organizational Behavior.

Rogerson, J., \& Kotze, N. (2011). Market segmentation and the changing South African hotel industry (1990 to 2010). African Journal of Business Management, 5(35).

Roth, A. (1995). Introduction to Experimental Economics.

Schermerhorn, J. (1993). Management for Productivity (6 ed.). Canada: John Wiley \& Sons. Shockley-Zalabak, P., Ellis, K., \& Winogard, G. (2000). Organizational trust: What it means, why it matters? Organizational Development. International Journal of Project Management, 19(1), 1-7. 
Sony, M., \& Mekoth, N. (2016). The relationship between emotional intelligence, frontline employee adaptability, job satisfaction and job performance. Journal of Retailing and Consumer Services, 30(1), 20-32.

Weerakkody, W., \& Perera, M. (2016). Impact of Job satisfaction on Job performance of nonexecutive employees in Hotel industry: With reference to Kalutara district in Sri Lanka.

Weiss, H. (2002). Deconstructing Job Satisfaction: Separating Evaluations, Beliefs and Affective Experiences. Human Resource Management Review, 12(2), 173-194.

\section{Acknowledgement}

The author wishes to express her heartfelt appreciation to the Executive and NonExecutive Staff members of the selected star class Hotels who supported in collecting relevant information for the study and to those who guided in numerous ways. 